\title{
Public knowledge of how to use an automatic external defibrillator in out-of-hospital cardiac arrest in Hong Kong
}

\author{
KL Fan, LP Leung *, HT Poon, HY Chiu, HL Liu, WY Tang
}

\section{A B S T R A C T}

Introduction: The survival rate of out-of-hospital cardiac arrest in Hong Kong is low. A long delay between collapse and defibrillation is a contributing factor. Public access to defibrillation may shorten this delay. It is unknown, however, whether Hong Kong's public is willing or able to use an automatic external defibrillator. This study aimed to evaluate public knowledge of how to use an automatic external defibrillator in out-of-hospital cardiac arrest.

Methods: A face-to-face semi-structured questionnaire survey of the public was conducted in six locations with a high pedestrian flow in Hong Kong.

Results: In this study, 401 members of the public were interviewed. Most had no training in first aid $(65.8 \%)$ or in use of an automatic external defibrillator (85.3\%). Nearly all (96.5\%) would call for help for a victim of out-of-hospital cardiac arrest but only $18.0 \%$ would use an automatic external defibrillator. Public knowledge of automatic external

This article was published on 31 Oct 2016 at www.hkmj.org. defibrillator use was low: $77.6 \%$ did not know the location of an automatic external defibrillator in the vicinity of their home or workplace. People who

had ever been trained in both first aid and use of an automatic external defibrillator were more likely to respond to and help a victim of cardiac arrest, and to use an automatic external defibrillator.

Conclusion: Public knowledge of automatic external defibrillator use is low in Hong Kong. A combination of training in first aid and in the use of an automatic external defibrillator is better than either one alone.

\section{Hong Kong Med J 2016;22:582-8} DOI: 10.12809/hkmj164896

\author{
${ }^{1} \mathrm{KL}$ Fan, MB, BS, FRCSEd \\ LP Leung *, MB, BS, FRCSEd \\ ${ }^{2}$ HT Poon \\ ${ }^{2}$ HY Chiu \\ ${ }^{2}$ HL Liu
}

${ }^{2}$ WY Tang

1 Emergency Medicine Unit, Li Ka Shing Faculty of Medicine, The University of Hong Kong, Pokfulam, Hong Kong

2 Li Ka Shing Faculty of Medicine, The University of Hong Kong, Pokfulam, Hong Kong

* Corresponding author: leunglp@hku.hk

New knowledge added by this study

- The prevalence of life-saving skills among Hong Kong citizens is low.

- Public knowledge of how to use an automatic external defibrillator is suboptimal.

Implications for clinical practice or policy

- A programme that increases public access to an increased number of available automatic external defibrillators is unlikely to be successful without also improving public knowledge.

- Combining first aid training with automatic external defibrillator training is better than either one alone with regard to bystander basic life support and defibrillation skills.

\section{Introduction}

Out-of-hospital cardiac arrest (OHCA) is a major cause of mortality globally. ${ }^{1}$ Despite major advances in the field of resuscitation, the survival-to-hospital discharge rate of OHCA in most regions is less than $10 \%{ }^{2}$ The crucial key lies in prehospital management. ${ }^{3}$ Research has shown that $53 \%$ of patients could be in ventricular tachycardia or ventricular fibrillation within 4 minutes of collapse in OHCA. ${ }^{4}$ Early defibrillation in the prehospital phase is required to terminate these rhythms and thus increase the chance of survival. Based on the same rationale, the strategy of public access defibrillation (PAD) was introduced almost 20 years ago. ${ }^{5}$ There is now increasing evidence that application of automatic external defibrillator (AED) in communities by lay bystanders improves survival following OHCA. ${ }^{6}$

Hong Kong has a population of about 7.3 million. ${ }^{7}$ As an international financial centre of the world and a metropolis of China, Hong Kong attracted nearly 61 million visitors from around the world in 2014. ${ }^{8}$ The annual incidence of OHCA is estimated to be 5000 to 6000 . The survival rate for non-traumatic OHCA to hospital discharge was between $1.25 \%$ and $3.00 \%{ }^{9-11}$ This survival rate is among the lowest compared with other Asian cities. ${ }^{12}$ 
Local studies have identified long time interval between collapse and first defibrillation as one of the factors contributing to the low survival rate. ${ }^{10,13}$ In 1995 , in order to shorten the collapse to defibrillation by first responder interval, AEDs were deployed in ambulances in Hong Kong. In 2006, the Government launched a PAD scheme whereby AED training was provided to emergency responders, eg police officers and other uniformed officers. Thereafter, AEDs have been installed in various places in Hong Kong, including public areas with a high public footfall. In Hong Kong, neither cardiopulmonary resuscitation nor use of an AED is a compulsory component of the school curriculum. The first aid courses organised by voluntary agencies may also not teach the use of an AED. The number of laypersons trained in use of an AED is unknown. It is also unknown whether a layperson is willing or able to use the AED. Studies of public knowledge about and attitudes to AED have been conducted in the United States, Europe, and Japan. ${ }^{14-16}$ There have been no similar investigations in Hong Kong or other Chinese cities. This study aimed to evaluate public knowledge about use of an AED in OHCA in Hong Kong. Such data could inform the health authorities when they are planning local PAD programmes.

\section{Methods}

This study was a face-to-face semi-structured questionnaire survey conducted on weekdays between 2 November 2015 and 15 December 2015 (excluding Saturdays and public holidays). The survey instrument was one adapted from an investigation carried out in the United Kingdom. ${ }^{17}$ Two investigators performed the forward and backward translation for the Chinese version to be used in the survey. It consisted of three sections. Section one collected demographic data. Questions in sections 2 and 3 assessed the response to an $\mathrm{OHCA}$ victim and knowledge of the use of an AED, respectively.

The survey was conducted daily from 18:00 to 22:00 during the study period in six locations across different districts of Hong Kong. Three locations were in the vicinity of a mass transit railway (MTR) station and the other three were close to a major shopping centre. These spots were chosen to ensure a high volume of pedestrians available for the survey. All pedestrians at the location formed the target population. One investigator from a team of three medical students and one nursing student approached the closest pedestrian, if possible one chosen at random. All investigators were trained how to administer the questionnaire in a standard manner. After introduction of the research, informed consent was obtained prior to completion of the questionnaire. A pedestrian would be recruited for the survey if he or she was aged 16 years or older

\section{香港市民對於使用自動體外除顫器替院外心跳 停止病人進行急救的知識掌握 樊潔玲、梁令邦、潘皓庭、趙翰璠、廖浩廉、鄧慧欣}

引言：香港院外心跳停止病人的存活率偏低, 其中一個主要原因是心 跳停止至除顫之間相隔太久所致。如果能在公眾地方使用自動體外除 顫器或可縮短延遲時間。然而, 目前未有資訊確定香港市民是否願意 或懂得使用自動體外除顫器。因此, 本研究旨在評估香港市民對於使 用自動體外除顫器替院外心跳停止病人進行急救的知識

方法：研究人員在香港人流量高的六個地點進行面訪, 讓被訪者回答 半結構化的問卷。

結果：成功訪問 401 名市民。大部分被訪者 $(65.8 \%$ ) 沒有任何急救培 訓, $85.3 \%$ 未曾使用自動體外除顫器。幾乎所有被訪者 $(96.5 \%)$ 如在 醫院範圍外遇到心跳停止的病人會向其他人求助, 但只有 $18.0 \%$ 會使 用自動體外除顫器。公眾對於使用自動體外除顫器進行急救的知識偏 低： $77.6 \% \%$ 並不清楚他們的住所或工作地點附近自動體外除顫器的 位置。曾經接受急救訓練或曾使用自動體外除顫器的被訪者較願意幫 助心跳停止的病人, 甚至會使用自動體外除顫器替患者進行急救。

結論：香港市民懂得使用自動體外除顫器的比率偏低。同時間接受急 救培訓及使用自動體外除顫器的訓練比只接受其中一項為佳。

and a permanent resident of Hong Kong. The only exclusion criterion was an inability to communicate in Chinese or English. Each recruited subject was asked for a response to each question, with no prompting, to determine their response to a victim in cardiac arrest and their knowledge of using an AED. The whole survey took about 20 minutes. No remuneration was received by the respondents. The study was approved by the Institutional Review Board of the University of Hong Kong/Hospital Authority Hong Kong West Cluster (Reference number: UW16-141).

The subject characteristics and their responses are described by descriptive statistics. Comparison was made between respondents who were and were not trained in first aid, and between those who were first aid-trained respondents with and without AED training. Significance testing was done by Chi squared test and Mann-Whitney $U$ test where appropriate. A P value of $<0.05$ was considered significant. Statistical analysis was performed by the Statistical Package for the Social Sciences (Windows version 23.0; SPSS Inc, Chicago [IL], US). For sample size, to attain a margin of error of $5 \%$ with a confidence level of $95 \%$ regarding pedestrians' response to an OHCA victim (assumed to be $50 \%$ to maximise the sample requirement), the minimum sample size was 385 .

\section{Results}

During the study period, there were a total of 192 sessions (32 days x 6 spots); 733 pedestrians 
were stopped and listened to the investigators' introduction, and were invited for an interview at one of the six locations. Overall, 42 did not fulfil the inclusion criteria; 401 accepted the invitation and completed the interview. On average, 3.8 pedestrians per session were invited for an interview and 2.0 pedestrians per session completed the interview. The response rate was 58\% (401/691) with a slight female predominance. Most were younger than 40 years and over half had attended university. The majority of respondents had no training in first aid $(65.8 \%)$ or use of an AED (85.3\%) [Table 1]. Of the 137 subjects trained in first aid, 49 were also trained in use of an AED. Although most respondents (96.5\%) would summon help for a victim of OHCA, only a minority of them were willing to do more, eg perform cardiopulmonary resuscitation (20.4\%) or apply an AED (18.0\%) [Table 2].

In general, knowledge about use of an AED was suboptimal (Table 3). Comparison of first aiders with non-first aiders revealed that first aiders had a more positive attitude in responding to a cardiac arrest victim and were more knowledgeable about the use of an AED (Table 4). When first aiders with and without AED training were compared, those with training were also more likely to respond to a cardiac arrest victim, be more knowledgeable about AED, and were more likely to try to locate an AED and apply it (Table 5).

\section{Discussion}

The response rate of this study was only $58 \%$ among those who stopped and listened to the investigators' introduction. The exact cause for the apparently small number of pedestrians being invited was unclear. One of the possibilities included extra time being spent in answering the queries of pedestrians and thus the time left for invitation was reduced. Further, part of the sessions fell within rush hour. Many pedestrians, especially those at the MTR stations, were in a hurry and reluctant to be interviewed.

This study revealed that approximately $34 \%$ of respondents were trained in first aid. This percentage is low in comparison to Sweden (45\%), New Zealand (74\%), and Washington (79\%) but comparable to Singapore (31\%). ${ }^{18-21}$ An even lower percentage (approximately 15\%) were trained in the use of AED. Although subject recruitment and sampling methods differed in these studies, both findings from this study raise concern about the prevalence of life-saving skills among Hong Kong citizens. It is reasonable to postulate that an $\mathrm{OHCA}$ victim in Hong Kong is less likely to receive life-saving support by a bystander as most have received no training in first aid or use of an AED. This is reflected by the incongruity between the willingness to summon help and reluctance to perform life-support procedures for an OHCA victim. After calling for help for the
TABLE I. Characteristics of respondents $(n=40$ I)

\begin{tabular}{|c|c|}
\hline Characteristic & No. (\%) of respondents* \\
\hline \multicolumn{2}{|l|}{ Gender } \\
\hline Male & $185(46.1)$ \\
\hline Female & $216(53.9)$ \\
\hline \multicolumn{2}{|l|}{ Age distribution (years) } \\
\hline $16-24$ & $155(38.7)$ \\
\hline $25-39$ & $154(38.4)$ \\
\hline $40-65$ & $86(21.4)$ \\
\hline$>65$ & $6(1.5)$ \\
\hline \multicolumn{2}{|l|}{ Education level attained } \\
\hline Uneducated or primary & 0 \\
\hline Secondary & $117(29.2)$ \\
\hline Matriculation or sub-degree & $72(18.0)$ \\
\hline University & $212(52.9)$ \\
\hline \multicolumn{2}{|l|}{ Ever had first aid training } \\
\hline Yes & $137(34.2)$ \\
\hline No & $264(65.8)$ \\
\hline \multicolumn{2}{|l|}{ Ever had AED training } \\
\hline Yes & $59(14.7)$ \\
\hline No & 342 (85.3) \\
\hline
\end{tabular}

Abbreviation: $A E D$ = automatic external defibrillator

* Because of rounding, not all percentages total 100

TABLE 2. Response to an OHCA victim

\begin{tabular}{|c|c|}
\hline Question & $\begin{array}{l}\text { No. }(\%) \text { of } \\
\text { respondents }\end{array}$ \\
\hline \multicolumn{2}{|c|}{ Would you call for help? } \\
\hline Yes & $387(96.5)$ \\
\hline No & $14(3.5)$ \\
\hline \multicolumn{2}{|c|}{ Would you assess the victim? } \\
\hline Yes & $183(45.6)$ \\
\hline No & $218(54.4)$ \\
\hline \multicolumn{2}{|c|}{ Would you commence CPR? } \\
\hline Yes & $86(21.4)$ \\
\hline No & $315(78.6)$ \\
\hline \multicolumn{2}{|c|}{$\begin{array}{l}\text { Would you perform CPR until an } \\
\text { ambulance arrived? }\end{array}$} \\
\hline Yes & $82(20.4)$ \\
\hline No & $319(79.6)$ \\
\hline \multicolumn{2}{|c|}{ Would you try to locate an AED? } \\
\hline Yes & $119(29.7)$ \\
\hline No & $282(70.3)$ \\
\hline \multicolumn{2}{|c|}{ Would you apply an AED if available? } \\
\hline Yes & $72(18.0)$ \\
\hline No & $329(82.0)$ \\
\hline
\end{tabular}

Abbreviations: AED = automatic external defibrillator; $\mathrm{CPR}=$ cardiopulmonary resuscitation; OHCA = out-of-hospital cardiac arrest 
TABLE 3. Knowledge about the use of an AED

\begin{tabular}{|c|c|}
\hline Question & No. (\%) of respondents \\
\hline \multicolumn{2}{|c|}{ Have you ever heard of AED? } \\
\hline Yes & $226(56.4)$ \\
\hline No & $175(43.6)$ \\
\hline \multicolumn{2}{|c|}{ Do you know that prompt use of an AED can increase survival? } \\
\hline Yes & $144(35.9)$ \\
\hline No & $257(64.1)$ \\
\hline \multicolumn{2}{|c|}{ Do you know the location of an AED nearest to your home or workplace? } \\
\hline Yes & $90(22.4)$ \\
\hline No & $311(77.6)$ \\
\hline \multicolumn{2}{|c|}{ Which one is the correct position for placement of the AED pads? (Diagram shown to respondents) } \\
\hline Correct answer & $62(15.5)$ \\
\hline Incorrect answer & $339(84.5)$ \\
\hline \multicolumn{2}{|c|}{ Do you know there is voice prompt in the AED? } \\
\hline Yes & $132(32.9)$ \\
\hline No & $269(67.1)$ \\
\hline
\end{tabular}

Abbreviation: $\mathrm{AED}=$ automatic external defibrillator

victim, most respondents would not try to locate an AED or use it if available. These findings suggest that there is an urgent need to implement communitybased education and training about sudden cardiac arrest and basic life support, including the use of an AED. The governments of many developed countries have invested heavily in recent years to promote PAD in their communities, eg the National Defibrillator Programme in the United Kingdom. ${ }^{22}$ The results of their efforts are encouraging with a significant number of lives saved.

In this study, the high rate of reluctance to use an AED may be explained by the suboptimal knowledge of the respondents. They performed particularly poorly in their knowledge of an AED location in the vicinity of their home or workplace and the actual operation of an AED. A comprehensive plan for promoting PAD, with raising the public awareness of the distribution of AED and teaching its operation as a priority, is indicated in Hong Kong. Further, because of the pervasiveness of mobile devices for information and communication, use of mobile apps to locate an AED may be useful. For example, mobile apps using GPS (Global Positioning System) technology to inform the potential responder to an OHCA victim of the whereabouts of an AED have to be explored. A Japanese study on the use of a mobile AED map has shown promising results. ${ }^{23}$

Combined first aid and AED training seems to be better than training in first aid alone. For first aiders who were also trained in AED, they were more likely to provide life-support intervention, including the use of an AED, to an OHCA victim. For any agency that organises first aid courses for the public, the inclusion of AED training should be considered.

\section{Limitations}

This study is limited by the response rate of approximately $58 \%$ that may be an overestimate as the number of pedestrians refusing the invitation right away were not included in the calculation. The investigators were unable to obtain the characteristics of the non-respondents for comparison. The respondents included for analysis in this study were relatively young and over half of them had a university education. This casts doubt on the representativeness of the sample. Representativeness was also undermined by the adoption of convenience sampling that is associated with selection bias of subjects for interviews. Caution is thus required when interpreting the results. Nonetheless it is reasonable to suggest that people of older age or with a lower education level are less likely to be more knowledgeable about AED than the young or those with a higher education level. Therefore, the findings from this study may underestimate the lack of knowledge about AED by the general public in Hong Kong. An additional caution in interpretation is information bias. Responses were self-reported and not validated. The respondents may have given what they considered to be socially desirable answers to the interviewers.

\section{Conclusion}

Public knowledge of AED in Hong Kong is low. 
TABLE 4. Comparison between first aiders and non-first aiders

\begin{tabular}{|c|c|c|c|}
\hline & \multicolumn{2}{|c|}{ No. (\%) of respondents } & \multirow[t]{2}{*}{$P$ value } \\
\hline & First aiders $(n=137)$ & Non-first aiders $(n=264)$ & \\
\hline \multicolumn{4}{|l|}{ Characteristics } \\
\hline Gender & & & 0.08 \\
\hline Male & $70(51.1)$ & $115(43.6)$ & \\
\hline Female & $67(48.9)$ & $149(56.4)$ & \\
\hline Age distribution (years) & & & 0.40 \\
\hline $16-24$ & $46(33.6)$ & $109(41.3)$ & \\
\hline $25-39$ & $60(43.8)$ & $94(35.6)$ & \\
\hline $40-65$ & $29(21.2)$ & $57(21.6)$ & \\
\hline$>65$ & $2(1.5)$ & $4(1.5)$ & \\
\hline Education level attained & & & 0.09 \\
\hline Uneducated or primary & 0 & 0 & \\
\hline Secondary & $30(21.9)$ & $87(33.0)$ & \\
\hline Matriculation or sub-degree & $27(19.7)$ & $45(17.0)$ & \\
\hline University & $80(58.4)$ & $132(50.0)$ & \\
\hline Ever had AED training & & & $<0.001$ \\
\hline Yes & $49(35.8)$ & $10(3.8)$ & \\
\hline No & $88(64.2)$ & $254(96.2)$ & \\
\hline \multicolumn{4}{|l|}{ Response to OHCA victim } \\
\hline Would you call for help? & & & 0.02 \\
\hline Yes & $136(99.3)$ & $251(95.1)$ & \\
\hline No & $1(0.7)$ & $13(4.9)$ & \\
\hline Would you assess the victim? & & & $<0.001$ \\
\hline Yes & $103(75.2)$ & $80(30.3)$ & \\
\hline No & $34(24.8)$ & $184(69.7)$ & \\
\hline Would you commence CPR? & & & $<0.001$ \\
\hline Yes & $65(47.4)$ & $21(8.0)$ & \\
\hline No & $72(52.6)$ & $243(92.0)$ & \\
\hline Would you perform CPR until an ambulance arrived? & & & $<0.001$ \\
\hline Yes & $64(46.7)$ & $18(6.8)$ & \\
\hline No & $73(53.3)$ & $246(93.2)$ & \\
\hline Would you try to locate an AED? & & & $<0.001$ \\
\hline Yes & $73(53.3)$ & $46(17.4)$ & \\
\hline No & $64(46.7)$ & $218(82.6)$ & \\
\hline Would you apply an AED if available? & & & $<0.001$ \\
\hline Yes & $57(41.6)$ & $15(5.7)$ & \\
\hline No & $80(58.4)$ & $249(94.3)$ & \\
\hline \multicolumn{4}{|l|}{ Knowledge about use of an AED } \\
\hline Have you ever heard of AED? & & & $<0.001$ \\
\hline Yes & $105(76.6)$ & $121(45.8)$ & \\
\hline No & $32(23.4)$ & $143(54.2)$ & \\
\hline Do you know that prompt use of an AED can increase survival? & & & $<0.001$ \\
\hline Yes & $72(52.6)$ & $72(27.3)$ & \\
\hline No & $65(47.4)$ & $192(72.7)$ & \\
\hline Do you know the location of an AED nearest to your home or workplace? & & & $<0.001$ \\
\hline Yes & $54(39.4)$ & $36(13.6)$ & \\
\hline No & $83(60.6)$ & $228(86.4)$ & \\
\hline $\begin{array}{l}\text { Which one is the correct position for placement of the AED pads? (Diagram } \\
\text { shown to respondents) }\end{array}$ & & & $<0.001$ \\
\hline Correct answer & $43(31.4)$ & $19(7.2)$ & \\
\hline Incorrect answer & $94(68.6)$ & $245(92.8)$ & \\
\hline Do you know there is voice prompt in the AED? & & & $<0.001$ \\
\hline Yes & $82(59.9)$ & $50(18.9)$ & \\
\hline No & 55 (40.1) & 214 (81.1) & \\
\hline
\end{tabular}

Abbreviations: $\mathrm{AED}$ = automatic external defibrillator; $\mathrm{CPR}=$ cardiopulmonary resuscitation; $\mathrm{OHCA}$ = out-of-hospital cardiac arrest 
TABLE 5. Comparison between first aiders with and without AED training

\begin{tabular}{|c|c|c|c|}
\hline & \multicolumn{2}{|c|}{ No. $(\%)$ of respondents } & \multirow[t]{2}{*}{$P$ value } \\
\hline & $\begin{array}{l}\text { With AED training } \\
\qquad(n=49)\end{array}$ & $\begin{array}{l}\text { Without AED training } \\
\qquad(\mathrm{n}=88)\end{array}$ & \\
\hline \multicolumn{4}{|l|}{ Characteristics } \\
\hline Gender & & & 0.33 \\
\hline Male & $22(44.9)$ & $48(54.5)$ & \\
\hline Female & $27(55.1)$ & $40(45.5)$ & \\
\hline Age distribution (years) & & & 0.30 \\
\hline $16-24$ & $14(28.6)$ & $32(36.4)$ & \\
\hline $25-39$ & $21(42.9)$ & $39(44.3)$ & \\
\hline $40-65$ & $14(28.6)$ & $15(17.0)$ & \\
\hline$>65$ & 0 & $2(2.3)$ & \\
\hline Education level attained & & & 0.74 \\
\hline Uneducated or primary & 0 & 0 & \\
\hline Secondary & $9(18.4)$ & $21(23.9)$ & \\
\hline Matriculation or sub-degree & $10(20.4)$ & $17(19.3)$ & \\
\hline University & $30(61.2)$ & $50(56.8)$ & \\
\hline \multicolumn{4}{|l|}{ Response to OHCA victim } \\
\hline Would you call for help? & & & 1.00 \\
\hline Yes & $49(100)$ & 87 (98.9) & \\
\hline No & 0 & $1(1.1)$ & \\
\hline Would you assess the victim? & & & 0.01 \\
\hline Yes & $43(87.8)$ & $60(68.2)$ & \\
\hline No & $6(12.2)$ & $28(31.8)$ & \\
\hline Would you commence CPR? & & & $<0.001$ \\
\hline Yes & $36(73.5)$ & $29(33.0)$ & \\
\hline No & $13(26.5)$ & $59(67.0)$ & \\
\hline Would you perform CPR until the ambulance arrived? & & & $<0.001$ \\
\hline Yes & $35(71.4)$ & $29(33.0)$ & \\
\hline No & $14(28.6)$ & $59(67.0)$ & \\
\hline Would you try to locate an AED? & & & $<0.001$ \\
\hline Yes & $41(83.7)$ & $32(36.4)$ & \\
\hline No & $8(16.3)$ & $56(63.6)$ & \\
\hline Would you apply an AED if available? & & & $<0.001$ \\
\hline Yes & $38(77.6)$ & $19(21.6)$ & \\
\hline No & $11(22.4)$ & $69(78.4)$ & \\
\hline \multicolumn{4}{|l|}{ AED knowledge } \\
\hline Have you ever heard of AED? & & & $<0.001$ \\
\hline Yes & $46(93.9)$ & $59(67.0)$ & \\
\hline No & $3(6.1)$ & $29(33.0)$ & \\
\hline Do you know that prompt use of AED can increase survival? & & & $<0.001$ \\
\hline Yes & $35(71.4)$ & $37(42.0)$ & \\
\hline No & $14(28.6)$ & $51(58.0)$ & \\
\hline Do you know the location of an AED nearest to your home or workplace? & & & 0.04 \\
\hline Yes & $25(51.0)$ & $29(33.0)$ & \\
\hline No & $24(49.0)$ & $59(67.0)$ & \\
\hline $\begin{array}{l}\text { Which one is the correct position for placement of the AED pads? (Diagram } \\
\text { shown to respondents) }\end{array}$ & & & 0.03 \\
\hline Correct answer & $23(46.9)$ & $20(22.7)$ & \\
\hline Incorrect answer & $26(53.1)$ & $68(77.3)$ & \\
\hline Do you know there is voice prompt in the AED? & & & $<0.001$ \\
\hline Yes & $46(93.9)$ & $36(40.9)$ & \\
\hline No & $3(6.1)$ & $52(59.1)$ & \\
\hline
\end{tabular}

Abbreviations: $\mathrm{AED}=$ automatic external defibrillator; $\mathrm{CPR}=$ cardiopulmonary resuscitation; $\mathrm{OHCA}=$ out-of-hospital cardiac arrest 
Simply increasing the number of AED devices installed is unlikely to be enough to increase its use in OHCA victims. A territory-wide PAD programme that couples first aid training with AED training may increase the use of AED in OHCA victims in Hong Kong. Use of mobile information technology, eg an AED locator app, should also be explored.

\section{Declaration}

All authors have disclosed no conflicts of interest.

\section{References}

1. Nichol G, Thomas E, Callaway CW, et al. Regional variation in out-of-hospital cardiac arrest incidence and outcome. JAMA 2008;300:1423-31.

2. Berdowski J, Berg RA, Tijssen JG, Koster RW. Global incidences of out-of-hospital cardiac arrest and survival rates: Systematic review of 67 prospective studies. Resuscitation 2010;81:1479-87.

3. McNally B, Robb R, Mehta M, et al. Out-of-hospital cardiac arrest surveillance-Cardiac Arrest Registry to Enhance Survival (CARES), United States, October 1, 2005December 31, 2010. MMWR Surveill Summ 2011;60:1-19.

4. Herlitz J, Ekström L, Wennerblom B, Axelsson A, Bång A, Holmberg S. Type of arrhythmia at EMS arrival on scene in out-of-hospital cardiac arrest in relation to interval from collapse and whether a bystander initiated CPR. Am J Emerg Med 1996;14:119-23.

5. Weisfeldt ML, Kerber RE, McGoldrick RP, et al. Public access defibrillation. A statement for healthcare professionals from the American Heart Association Task Force on Automatic External Defibrillation. Circulation 1995;92:2763.

6. Weisfeldt ML, Sitlani CM, Ornato JP, et al. Survival after application of automatic external defibrillators before arrival of the emergency medical system: evaluation in the resuscitation outcomes consortium population of 21 million. J Am Coll Cardiol 2010;55:1713-20.

7. Census and Statistics Department, Hong Kong SAR Government. Population. 2014. Available from: http:// www.censtatd.gov.hk/hkstat/sub/so20.jsp. Accessed 5 Jan 2016.

8. Tourism Commission, Commerce and Economic Development Bureau, Hong Kong SAR Government. Tourism performance in 2014. Available from: http://www. tourism.gov.hk/english/statistics/statistics_perform.html. Accessed 5 Jan 2016.

9. Wong TW, Yeung KC. Out-of-hospital cardiac arrest: two and a half years experience of an accident and emergency department in Hong Kong. J Accid Emerg Med 1995;12:349.

10. Lui JC. Evaluation of the use of automatic external defibrillation in out-of-hospital cardiac arrest in Hong Kong. Resuscitation 1999;41:113-9.

11. Leung LP, Wong TW, Tong HK, Lo CB, Kan PG. Out-ofhospital cardiac arrest in Hong Kong. Prehosp Emerg Care 2001;5:308-11.

12. Ong ME, Shin SD, De Souza NN, et al. Outcomes for out-of-hospital cardiac arrests across 7 countries in Asia: The Pan Asian Resuscitation Outcomes Study (PAROS). Resuscitation 2015;96:100-8.

13. Fan KL, Leung LP. Prognosis of patients with ventricular fibrillation in out-of-hospital cardiac arrest in Hong Kong: prospective study. Hong Kong Med J 2002;8:318-21.

14. Kozłowski D, Kłosiewicz T, Kowalczyk A, et al. The knowledge of public access to defibrillation in selected cities in Poland. Arch Med Sci 2013;9:27-33.

15. Taniguchi T, Sato K, Kurita A, Noda T, Okajima M. Attitudes toward automated external defibrillator use in Japan in 2011. J Anesth 2014;28:34-7.

16. Gonzalez M, Leary M, Blewer AL, et al. Public knowledge of automatic external defibrillators in a large U.S. urban community. Resuscitation 2015;92:101-6.

17. Brooks B, Chan S, Lander P, Adamson R, Hodgetts GA, Deakin CD. Public knowledge and confidence in the use of public access defibrillation. Heart 2015;101:967-71.

18. Axelsson AB, Herlitz J, Holmberg S, Thorén AB. A nationwide survey of CPR training in Sweden: foreign born and unemployed are not reached by training programmes. Resuscitation 2006;70:90-7.

19. Larsen P, Pearson J, Galletly D. Knowledge and attitudes towards cardiopulmonary resuscitation in the community. N Z Med J 2004;117:U870.

20. Sipsma K, Stubbs BA, Plorde M. Training rates and willingness to perform CPR in King County, Washington: a community survey. Resuscitation 2011;82:564-7.

21. Ong ME, Quah JL, Ho AF, et al. National population based survey on the prevalence of first aid, cardiopulmonary resuscitation and automated external defibrillator skills in Singapore. Resuscitation 2013;84:1633-6.

22. UK Department of Health. National Defibrillator Programme. 2010. Available from: http://webarchive. nationalarchives.gov.uk/+/www.dh.gov.uk/en/Healthcare/ Longtermconditions/Vascular/Coronaryheartdisease/ Coronarypromotionproject/index.htm. Accessed 1 Feb 2016.

23. Sakai T, Iwami T, Kitamura T, et al. Effectiveness of the new 'Mobile AED Map' to find and retrieve an AED: A randomised controlled trial. Resuscitation 2011;82:6973. 